Studia Anglica Posnaniensia 48, 4, 2013

doi: 10.2478/stap-2013-0012

\title{
LINGUISTICS
}

\section{MODALS, SPEECH ACTS AND (IM)POLITENESS: INTERACTIONS IN SHAKESPEARE'S PLAYS ${ }^{1}$}

\author{
MINAKO NAKAYASU
}

Hamamatsu University School of Medicine, Hamamatsu, Japan

\begin{abstract}
This paper accounts for how modals are interrelated with speech acts and (im)politeness, to offer a new perspective to the interactions in Shakespeare's plays.

A variety of strategies to save or attack the hearer's positive or negative face are taken into account within the frameworks of Brown \& Levinson (1987) and Culpeper (1996), and the interplay between these strategies is observed in relation to the modals. Furthermore, this study analyses how speech acts performed with the aid of modals are associated with (im)politeness strategies, based on the inventory of speech acts proposed by Nakayasu (2009).

It has been shown that there are more strategies to save or attack the hearer's positive face in Shakespeare which are employed with the use of modals. The analysis reinforces the proposal by Kopytko $(1993,1995)$ that social interactions in Shakespeare's time were positive politenessoriented, going further to extend the analysis to impoliteness, and suggests the interrelated nature of modality, speech acts and (im)politeness.
\end{abstract}

Keywords: speech acts, impoliteness, modals, Shakespeare's plays

The earlier versions of this paper were read at the 9th International Pragmatics Conference in 2009 and the 16th International Conference on English Historical Linguistics in 2010. This research is partially supported by the Grant-in-Aid for Scientific Research (C) from the Japan Society of the Promotion of Science, and a faculty grant from the Research Institute for Humanities, Gakushuin University. I gratefully acknowledge these grants. I would like to thank two anonymous reviewers, who equipped me with their splendid ideas to improve this paper. Special thanks are also due to Andreas H. Jucker, Irma Taavitsainen, and Hiroyuki Takada and each member of his historical pragmatic research group. The spelling of this paper follows British convention throughout, aside from a couple of exceptions where the original authors employ American convention (Brown \& Levinson 1987 and Evans 1997). 


\section{Introduction}

Recent research has brought to light pragmatic and sociolinguistic aspects of language in history. (Im)politeness, a system of verbal behaviours to pay attention to another person's facial wants, is certainly a topic in this area, and it is only recently that (im)politeness in the history of English has been seriously discussed (Brown \& Gilman 1989; Kopytko 1993, 1995; Rudanko 2006; Jucker 2008; Kohnen 2008; Culpeper \& Kádár 2010; Nevala 2010; Bax \& Kádár 2011; Jucker 2011, 2012, etc.). I will start the discussion by offering the following examples from Shakespeare's plays:

$$
\text { Ar. (...) }
$$

Sweet, adieu. I'll keep my oath,

Patiently to bear my wroth.

$(\mathrm{MV} 2.9 .77-78)^{2}$

In the example (1) above, the speaker Arragon makes a promise to the hearer Portia, which sounds polite to her. Note also that he uses the modal 'LL (contracted form) when making the promise. In the following example (2), on the other hand, the speaker Shylock employs the 'imperative (Repair thy wit) + or + the modal (WILL)' pattern to be threatening and impolite to the hearer:

(2) Shy. Till thou canst rail the seal from off my bond, Thou but offend'st thy lungs to speak so loud.

Repair thy wit, good youth, or it will fall

To cureless ruin. I stand here for law.

(MV 4.1.139-142)

Two significant elements seem to be relevant here: modals (modality) and speech acts. It is widely accepted that modals are closely connected to the speaker's attitude and have unique functions in discourse (Boyd \& Thorne 1969; Arnovick 1999; Palmer 2001; Nakayasu 2009 etc.). It is therefore reasonable to assume that they play an important role in language interactions, whose major aspects are (im)politeness and speech acts. It seems that speech acts in relation to modals have been relatively accessible to historical researchers, for example, Arnovick (1990, 1999), and Gotti et al. (2002). No study, however, has attempted a systematic analysis of the relationship between modals and (im)politeness in the history of English. This is possibly because (im)politeness in language is not a topic of expressions such as honorifics, but rather of a principle covering whole language

2 MV stands for The merchant of Venice, as will be seen later in Section 1. 
use. As pointed out by Jucker \& Taavitsainen (2008) and Taavitsainen \& Jucker (2008), some particular speech acts such as apology can be face-threatening and the analysis of their historical development shows the relationship between speech acts and (im)politeness. In historical contexts, then, how are modals used as part of (im)politeness strategies in interaction? What kind of strategies are exploited in order to be polite or impolite to the hearer? Furthermore, how is (im)politeness related to speech acts? These questions will naturally arise from examining the contexts such as (1) and (2) above.

The purpose of this paper is to account for how modals are interrelated with pragmatic and sociolinguistic aspects, that is, speech acts and (im)politeness, to offer a new perspective to the interaction in Shakespeare's plays. The theory and methodology of the present paper follow Brown \& Levinson (1987) and Culpeper (1996) on (im)politeness, Culpeper \& Kádár (2010) on historical (im)politeness, and Nakayasu (2009) on modals and speech acts. ${ }^{3}$ The text used for analysis is The Riverside Shakespeare (Evans 1997). The instances of utterances which contain the modals are identified with the aid of Spevack's (19681980) concordance. The corpus consists of four of Shakespeare's plays:

Table 1. The corpus

\begin{tabular}{l|l}
\hline Play & Number of words \\
\hline Antony and Cleopatra (ANT); tragedy and history & 26,299 \\
\hline Julius Caesar (JC); tragedy and history & 20,764 \\
\hline Love's labor's lost (LLL); comedy & 22,819 \\
\hline The merchant of Venice (MV); comedy & 22,602 \\
\hline Total & 92,484 \\
\hline
\end{tabular}

The choice of plays maintains a symmetry of tragedies and comedies, and also offers a properly wide spectrum of dialogues among speakers of various social backgrounds. ${ }^{4}$ The direction of mapping is both form-to-function and function-

3 It should be noted that there are many objections to Brown \& Levinson's (1987) theory on politeness. See, for example, Bax \& Kádár (2011: 14-17). The present research, however, follows Brown \& Levinson (1987) and Culpeper (1996), the latter of which is derived from Brown \& Levinson (1987), because their theory remains the standard. I also refer to Brown \& Gilman (1989) and Kopytko (1993) for politeness strategies, which are based on Brown \& Levinson's (1987) theory, and for impoliteness strategies, Bousfield (2008), which develops Culpeper's (1996) proposal.

4 The corpus includes speakers of various social ranks, i.e., sovereign, upper, profession, middle, and lower. See Nevalainen \& Raumolin-Brunberg (1996) and Nakayasu (2009). 
to-form (Jacobs \& Jucker 1995); therefore it is necessary to limit the scope of corpus in order to conduct an in-depth analysis of the context. The modals under investigation are proximal modals SHALL and WILL, distal modals SHOULD and WOULD, and the contracted form 'LL. Table 2 below shows the frequency of each modal in the corpus, giving the numbers of instances and the normalised figures per 10,000 words:

Table 2. Frequency in the corpus

\begin{tabular}{l|l|l}
\hline Modal & Instances & $/ 10,000$ words \\
\hline SHALL & 475 & 51.4 \\
\hline SHOULD & 192 & 20.8 \\
\hline WILL & 575 & 62.2 \\
\hline WOULD & 248 & 26.8 \\
\hline 'LL & 211 & 22.8 \\
\hline Total & 1,701 & 183.9 \\
\hline
\end{tabular}

Among the so-called central modals, these four modals frequently occur and are fairly well researched, though there is still plenty of room for further research into their pragmatic and sociolinguistic aspects. The present paper is based on and goes beyond Nakayasu's (2009) investigations on the pragmatic aspects of these modals, speech acts and politeness in particular.

Before proceeding, it is helpful to briefly describe the range of meanings the modals can express. Modality is a grammatical category which is typically represented by modals, and concerned with the status of the proposition which expresses the event (Palmer 2001, etc.). The present research assumes a trichotomy for modality: epistemic, deontic, and dynamic, following the theory by Palmer (2001). Epistemic modality describes the speaker's judgement of the factual status of the proposition or the state of affairs represented in the proposition:

(3) $\quad[$ Ant. $](\ldots)$

Over thy wounds now do I prophesy

(...)

A curse shall light upon the limbs of men;

(JC 3.1.259-262)

Deontic modality describes the state of affairs represented in the proposition, which has not yet been actualised. The conditioning factor is outside the relevant individual, as in the cases of obligation, permission, or the speaker's intention: 
Although dynamic modality also describes the state of affairs not yet actualised, the crucial difference from deontic modality is the whereabouts of the conditioning factor: it is inside the relevant individual, as in the cases of ability, nature or willingness:

(5) $(=(1))$

Ar. (...)

Sweet, adieu. I'll keep my oath,

Patiently to bear my wroth.

(MV 2.9.77-78)

The idea of the proximal/distal distinction is taken from that of deixis, a system of 'pointing' (Fillmore 1975 [1997], etc.). The entities close to the here and now of the speaker are referred to as proximal, while those distant from them are as distal (Diessel 1999, etc.). The modals SHALL, WILL, 'LL are considered proximal, whereas the modals SHOULD and WOULD are distal. These distal forms of modals, though they are often called 'past modals', can express a range of meanings which the past tense can signify (Oakeshott-Taylor 1984). The temporal meaning signifies that the situation is temporally distant from the here and now of the speaker, i.e. in the past:

4. Pleb. Mark'd ye his words? He would not take the crown, Therefore 'tis certain he was not ambitious.

(JC 3.2.112-113)

The metaphorical meaning, by contrast, describes the situation as distant from the direct speech act, i.e. the speaker is politely talking to the addressee:

Ros. Pray you, do my commendations - I would be glad to see it.

In the hypothetical meaning, the situation is distant from the fact, i.e. it is a hypothetical situation:

(8) Eno. Would we had all such wives, that the men might go to wars with the women! 
The speaker takes advantages of these meanings when he/she employs (im)politeness strategies.

In the following, I will conduct statistical and contextual analyses of utterances which include these modals. ${ }^{5}$ I will first examine (im)politeness strategies (politeness/impoliteness and positive/negative), observe the interplay between modals and strategies and among the strategies, and then analyse how speech acts are related to (im)politeness strategies.

\section{2. (Im)politeness strategies}

'Politeness' and its negative counterpart 'impoliteness' consist of a system of verbal behaviours to pay attention to another person's facial wants (Brown \& Levinson 1987, etc.). ${ }^{6}$ Politeness strategies are employed to save face in order to contribute to social harmony, while impoliteness strategies aim at attacking face in order to cause social disharmony (Culpeper 1996, etc.). Face, a public selfimage of every member of a society, is an ambivalent notion which has a positive side (positive face, i.e. approach-based) and a negative side (negative face, i.e. avoidance-based). Positive politeness, for example, is oriented toward the positive face of the hearer, i.e. their desire to be a member of a group, and therefore guarantees that FTAs (face-threatening acts) do not mean a negative evaluation of the hearer's positive face. Negative politeness, on the other hand, pays respect to the negative face of the hearer, i.e. their claims of territory and freedom of action, and therefore redresses the FTAs so that it will not impede the hearer's wants.

This section will analyse how these (im)politeness strategies are employed in cooperation with the modals to save or attack positive/negative face of the hearer in Shakespeare's plays. The analysis is conducted on the utterances which include a modal and of the contexts where they occur to assign those utterances to one of the (im)politeness strategy categories. Expressions which reinforce a certain interpretation are also taken into consideration, such as for thy humor (positive politeness; JC 2.2.56), Pardon me (negative politeness; MV 5.1.219), I say (positive impoliteness; LLL 5.2.514), and speak no more (negative impoliteness; ANT 2.2.107). Though one modal instance is generally assigned one strategy category, it is also possible to be assigned more than one in

5 The statistical analysis in this paper is descriptive, not inferential, i.e. it describes the results of the analysis within the data set, not inferentially expanding the results beyond it.

6 Jucker (2011) discusses positive and negative face and politeness in the history of English, and points out that these categories become clearly more useful for analytical purposes in Early Modern English than in Middle English. 
a limited number of cases. Table 3 below shows the number and proportion of modal instances which are not assigned to any category of (im)politeness strategy (1,060 instances; $62.3 \%$ ), and likewise, the number and proportion of those instances of each individual modal which are not assigned to any category of (im)politeness strategy: ${ }^{7}$

Table 3. Instances not assigned an (im)politeness strategy

\begin{tabular}{|l|l|l|l|}
\hline Modal & Instances & No strategy & Percentage \\
\hline SHALL & 475 & 294 & 61.9 \\
\hline SHOULD & 192 & 135 & 70.3 \\
\hline WILL & 575 & 340 & 59.1 \\
\hline WOULD & 248 & 181 & 73.0 \\
\hline 'LL & 211 & 110 & 52.1 \\
\hline Total & 1,701 & 1,060 & 62.3 \\
\hline
\end{tabular}

The following subsections will analyse each of the (im)politeness strategies which are employed with the aid of the modals.

\subsection{Politeness strategies}

Positive politeness strategies (abbreviated here as PP) are utilized to save the positive face of the hearer. The present research assumes 16 strategies following Brown \& Levinson (1987) and Brown \& Gilman (1989) (PP16 is proposed by Kopytko (1993)). ${ }^{8}$ Table 4 below itemises each of these strategies in cooperation with the modals, the examples in my corpus, and the number of their instances: ${ }^{9}$

7 Among the instances which are not categorised as occurring in any (im)politeness strategy, this paper includes 'mock politeness' instances, 'mock impoliteness' instances, 'aside' instances (i.e. the speaker does not address the hearer but talks aside), and bold-on-record instances.

8 Brown \& Levinson (1987) argue that the speaker tends to utilize the strategies minimizing face-threatening acts (FTAs) according to a rational assessment of the face risk to the hearer. For the details of each (im)politeness strategy, see Brown \& Levinson (1987); Kopytko (1993); Culpeper (1996); Bousfield (2008), etc.

9 The example of each strategy category is not included in the list if no instance of that strategy is recorded in my corpus. For examples of the strategies, see Brown \& Levinson (1987); Brown \& Gilman (1989); Kopytko (1993); Culpeper (1996); Bousfield (2008), etc. 
Table 4. Uses of modals in positive politeness strategies (PP)

\begin{tabular}{|c|c|c|}
\hline Number & Strategy & Instances \\
\hline 1. & $\begin{array}{l}\text { Notice admirable qualities, possessions, etc. } \\
\text { Lep. Till I shall see you in your soldier's dress, } \\
\text { Which will become you both, farewell. (ANT 2.4.4-5) }\end{array}$ & 15 \\
\hline 2. & $\begin{array}{l}\text { Exaggerate sympathy, approval, etc. } \\
\text { Bru. It was well done, and thou shalt sleep again; } \\
\text { I will not hold thee long. (JC 4.3.264-265) }\end{array}$ & 13 \\
\hline 3. & $\begin{array}{l}\text { Intensify the interest of the hearer in the speaker's con- } \\
\text { tribution } \\
\text { Arm. I will tell thee wonders. (LLL 1.2.139) }\end{array}$ & 5 \\
\hline 4. & $\begin{array}{l}\text { The use of in-group identity markers in speech } \\
\text { Ant. He will not fight with me, Domitius? (ANT 4.2.1) }\end{array}$ & 13 \\
\hline 5. & $\begin{array}{l}\text { Seek agreement in safe topics } \\
\text { Cas. (...) If we do meet again, why, we shall smile; (JC } \\
5.1 .117)\end{array}$ & 6 \\
\hline 6. & $\begin{array}{l}\text { Avoid possible disagreement by hedging the speaker's } \\
\text { statement } \\
\text { Bru. I would not, Cassius, yet I love him well. (JC } \\
1.2 .82 \text { ) }\end{array}$ & 2 \\
\hline 7. & Assert common ground & 0 \\
\hline 8. & $\begin{array}{l}\text { Joke to put the hearer at ease } \\
\text { Iras. No, you shall paint when you are old. (ANT } \\
1.2 .19 \text { ) }\end{array}$ & 43 \\
\hline 9. & $\begin{array}{l}\text { Assert knowledge of the hearer's wants and indicate } \\
\text { the speaker is taking account } \\
\text { Caes. Mark Antony shall say I am not well, } \\
\text { And for thy humor I will stay at home. (JC } 2.2 .55-56 \text { ) }\end{array}$ & 15 \\
\hline 10. & $\begin{array}{l}\text { Offer, promise } \\
\text { Ar. (...) Sweet, adieu. I'll keep my oath, } \\
\text { Patiently to bear my wroth. (MV 2.9.77-78) }\end{array}$ & 165 \\
\hline 11. & $\begin{array}{l}\text { Being optimistic that the hearer wants what the speaker } \\
\text { wants, that the FTA is slight } \\
\text { Ant. We will yet do well. (ANT 3.13.187) }\end{array}$ & 32 \\
\hline 12. & $\begin{array}{l}\text { Use an inclusive form to include both the speaker and } \\
\text { the hearer in the activity } \\
\text { Cleo. (...) Come, you'll play with me, sir? (ANT 2.5.6) }\end{array}$ & 33 \\
\hline
\end{tabular}




\begin{tabular}{|c|l|c|}
\hline 13. & $\begin{array}{l}\text { Give reasons why the speaker wants what he or she } \\
\text { does so that it will seem reasonable to the hearer } \\
\text { Bru. Your reason? } \\
\text { Cas. This it is: } \\
\text { 'Tis better that the enemy seek us; } \\
\text { So shall he waste his means, weary his soldiers, } \\
\text { Doing himself offense, (...) (JC 4.3.198-201) }\end{array}$ & 27 \\
\hline 14. & $\begin{array}{l}\text { Assert reciprocal exchange or tit for tat } \\
\text { Cleo. (..) but since my lord } \\
\text { Is Antony again, I will be Cleopatra. (ANT 3.13.185- } \\
\text { 186) }\end{array}$ & 19 \\
\hline 15. & $\begin{array}{l}\text { Give something desired: gifts, position, sympathy, } \\
\text { understanding } \\
\text { Cleo. Say 'tis not so, a province I will give thee, } \\
\text { And make thy fortunes proud; (ANT 2.5.68-69) }\end{array}$ & 17 \\
\hline 16. & $\begin{array}{l}\text { Satisfy the hearer's informational deficit (Kopytko) } \\
\text { Var. This is most certain that I shall deliver; } \\
\text { Mark Antony is every hour in Rome } \\
\text { Expected. (ANT 2.1.28-30) }\end{array}$ & 25 \\
\hline \multicolumn{2}{|c}{ Total } & 430 \\
\hline
\end{tabular}

PP10 (Offer, promise) is by far the most frequent strategy, followed by PP8 (Joke to put the hearer at ease), PP12 (The use of an inclusive form to include both the speaker and the hearer in the activity), and PP11 (Being optimistic that the hearer wants what the speaker wants, that the FTA is slight). This result supports Kopytko's $(1993: 73$, 99) observation that PP10 enjoys the highest frequency in Shakespeare, although he covers all the strategies irrespective of whether modals are used or not. Recall that in (1) the speaker makes a promise to be polite to the hearer. In this example, the contracted form of the modal 'LL, whose dynamic modality expresses the speaker Arragon's intention, plays a significant role to make a promise. It is iterated in (9) below for the sake of convenience:

(9) (=(1)) PP10 (Offer, promise)

Ar. (...)

Sweet, adieu. I'll keep my oath,

Patiently to bear my wroth.

(MV 2.9.77-78)

With the aid of negative politeness strategies (abbreviated as PN), the speaker tries to save the negative face of the hearer. Brown \& Levinson (1987) and Brown \& Gilman (1989) assume the following 10 strategies: 
Table 5. Uses of modals in negative politeness strategies (PN)

\begin{tabular}{|c|c|c|}
\hline Number & Strategy & Instances \\
\hline 1. & $\begin{array}{l}\text { Being conventionally indirect } \\
\text { Bass. May you stead me? Will you pleasure me? } \\
\text { Shall I know your answer? (MV 1.3.7-8) }\end{array}$ & 25 \\
\hline 2. & $\begin{array}{l}\text { Not assuming willingness to comply - question, } \\
\text { hedge } \\
\text { Por. (...) One half of me is yours, the other half yours } \\
\text { - } \\
\text { Mine own, I would say; (MV 3.2.16-17) }\end{array}$ & 24 \\
\hline 3. & $\begin{array}{l}\text { Being pessimistic about ability or willingness to } \\
\text { comply - using the subjunctive } \\
\text { Agr. (...) By this marriage, } \\
\text { All little jealousies, which now seem great, } \\
\text { And all great fears, which now import their dangers, } \\
\text { Would then be nothing. (ANT 2.2.130-133) }\end{array}$ & 15 \\
\hline 4. & $\begin{array}{l}\text { Minimizing the imposition } \\
\text { Dol. I am loath to tell you what I would you knew. } \\
\text { (ANT 5.2.107) }\end{array}$ & 2 \\
\hline 5. & $\begin{array}{l}\text { Giving deference } \\
\text { Por. Here; what would my lord? (MV 2.9.85) }\end{array}$ & 15 \\
\hline 6. & $\begin{array}{l}\text { Apologizing - admitting impingement, expressing } \\
\text { reluctance, asking for forgiveness } \\
\text { Bass. (...) What should I say, sweet lady? } \\
\text { (...) Pardon me, good lady, (MV 5.1.215-219) }\end{array}$ & 5 \\
\hline 7. & $\begin{array}{l}\text { Impersonalizing the speaker and the hearer. Using the } \\
\text { passive without agent } \\
\text { Bass. Our feast shall be much honored in your } \\
\text { marriage. (MV 3.2.212) }\end{array}$ & 5 \\
\hline 8. & $\begin{array}{l}\text { Stating the FTA as an instance of a general rule to } \\
\text { soften the offence }\end{array}$ & 0 \\
\hline 9. & Nominalizing to distance the actor and add formality & 0 \\
\hline 10. & Going on record as incurring a debt & 0 \\
\hline \multicolumn{2}{|r|}{ Total } & 91 \\
\hline
\end{tabular}

Kopytko (1993: 85) notes that Shakespeare uses PN2 (Not assuming willingness to comply - question, hedge) "quite often"; the second most common strategy in his corpus is PN6 (Apologize - admitting impringement, expressing reluctance, asking for forgiveness). Table 5 shows that in my corpus of modals, 
PN1 (Being conventionally indirect) and PN2 are the most frequent. As the following (10) demonstrates, modals are effectively used in interrogative sentences to make a indirect request: ${ }^{10}$

(10) PN1 (Be conventionally indirect)

Bass. May you stead me? Will you pleasure me?

Shall I know your answer?

Shy. Three thousand ducats for three months, and Antonio bound.

(MV 1.3.7-10)

Employing distal modals is also a typical strategy for negative politeness:

(11) PN3 (Being pessimistic about ability or willingness to comply - using the subjunctive)

Agr. (...) By this marriage,

All little jealousies, which now seem great,

And all great fears, which now import their dangers,

Would then be nothing. Truths would be tales,

Where now half tales be truths. Her love to both

Would each to other and all loves to both

Draw after her. Pardon what I have spoke,

For 'tis a studied, not a present thought,

By duty ruminated.

(ANT 2.2.130-138)

In the above, the speaker Agrippa is suggesting that Antony should marry Octavia. He is not forcing him to marry her, but making a prediction using distal modals regarding what would happen if he could marry her, leaving measure of freedom to say 'no'; namely, he is paying respect to his negative face.

\subsection{Impoliteness strategies}

Positive impoliteness strategies (abbreviated as IP) are intended to attack the positive face of the hearer. Culpeper (1996) assumed 10 such strategies, and Bousfield (2008) elaborated on them by adding 2 more to the list. Table 6 shows the strategies in relation to the modals and their instances:

10 The two utterances in (10), Will you pleasure me? and Shall I know your answer? are counted as two instances in Table 5. 
Table 6. Uses of modals in positive impoliteness strategies (IP)

\begin{tabular}{|c|c|c|}
\hline Number & Strategy & Instances \\
\hline 1. & $\begin{array}{l}\text { Ignoring, snubbing the other - failing to acknowledge } \\
\text { the other's presence } \\
\text { Shy. I'll have my bond; I will not hear thee speak. } \\
\text { (MV 3.3.12) }\end{array}$ & 16 \\
\hline 2. & Excluding the other from an activity & 0 \\
\hline 3. & $\begin{array}{l}\text { Disassociating from the other - denying association } \\
\text { or common ground with the other; avoiding sitting } \\
\text { together } \\
\text { Ant. I'll leave you, lady. (ANT 1.3.86) }\end{array}$ & 7 \\
\hline 4. & Being disinterested, unconcerned, unsympathetic & 0 \\
\hline 5. & $\begin{array}{l}\text { Using inappropriate identity markers - using title and } \\
\text { surname when a close relationship pertains, or a } \\
\text { nickname when a distant relationship pertains }\end{array}$ & 0 \\
\hline 6. & $\begin{array}{l}\text { Using obscure or secretive language - mystifying the } \\
\text { other with jargon, or using a code known to others in } \\
\text { the group, but not the target } \\
\text { Laun. To be brief, the very truth is that the Jew, } \\
\text { having done me wrong, doth cause me, as my father, } \\
\text { being I hope an old man, shall frutify unto you - } \\
\text { (MV 2.2.132-134) }\end{array}$ & 5 \\
\hline 7. & $\begin{array}{l}\text { Seeking disagreement - selecting a sensitive topic } \\
\text { Prin. Why, will shall break it, will, and nothing else. } \\
\text { (LLL 2.1.100) }\end{array}$ & 7 \\
\hline 8. & $\begin{array}{l}\text { Avoiding agreement (Bousfield) } \\
\text { Cleo. Sir, I will eat no meat, I'll not drink, sir; (ANT } \\
\text { 5.2.49) }\end{array}$ & 11 \\
\hline 9. & $\begin{array}{l}\text { Making the other feel uncomfortable - do not avoid } \\
\text { silence, joke, or use small talk } \\
\text { King. I say they shall not come. (LLL 5.2.514) }\end{array}$ & 7 \\
\hline 10. & $\begin{array}{l}\text { Using taboo words - swearing or using abusive or } \\
\text { profane language }\end{array}$ & 0 \\
\hline 11. & $\begin{array}{l}\text { Calling the other names }- \text { using derogatory } \\
\text { nominations } \\
\text { Ant. Tug him away. Being whipt, } \\
\text { Bring him again; the Jack of Caesar's shall } \\
\text { Bear us an arrant to him. (ANT 3.13.103-104) }\end{array}$ & 2 \\
\hline
\end{tabular}




\begin{tabular}{l|l|c}
\hline 12. & $\begin{array}{l}\text { Criticising - dispraising the hearer, some action or } \\
\text { interaction by the hearer, or some entity in which the } \\
\text { hearer has invested face (Bousfield) } \\
\text { Bru. You have done that you should be sorry for. (JC } \\
\text { 4.3.65) }\end{array}$ & \\
\hline \multicolumn{2}{c}{ Total } & 70 \\
\hline
\end{tabular}

In the following context (12), the speaker Shylock completely neglects what Antonio says: in other words, he attacks his positive face by ignoring him. He employs the modal WILL and the contracted form 'LL, either in positive or negative form, both of which express his strong intention:

(12) IP1 (Ignore, snub the other - fail to acknowledge the other's presence) Ant. I pray thee hear me speak.

Shy. I'll have my bond; I will not hear thee speak.

I'll have my bond, and therefore speak no more.

I'll not be made a soft and dull-ey'd fool

To shake the head, relent, and sigh, and yield

To Christian intercessors. Follow not,

I'll have no speaking, I will have my bond. Exit Jew.

(MV 3.3.11-17)

Negative impoliteness strategies (abbreviated as IN) are used to attack the negative face of the hearer. Bousfield (2008) adds 2 more strategies to Culpeper's (1996), obtaining 7 strategies:

Table 7. Uses of modals in negative impoliteness strategies (IN)

\begin{tabular}{c|l|c}
\hline Number & Strategy & Instances \\
\hline 1. & $\begin{array}{l}\text { Frightening }- \text { instilling the belief that action } \\
\text { detrimental to the other will occur } \\
\text { Shy. (..) Repair thy wit, good youth, or it will fall } \\
\text { To cureless ruin. (MV 4.1.141-142) }\end{array}$ & 23 \\
\hline 2. & $\begin{array}{l}\text { Condescending, scorning or ridiculing - emphasising } \\
\text { your relative power; being contemptuous } \\
\text { Eno. (..) You shall have time to wrangle in when you } \\
\text { have nothing else to do. (ANT 2.2.105-106) }\end{array}$ & 8 \\
\hline 3. & $\begin{array}{l}\text { Invading the other's space - literally (positioning } \\
\text { yourself closer to the other than the relationship } \\
\text { permits) or metaphorically (asking for or speaking } \\
\text { about information which is too intimate given the } \\
\text { relationship) }\end{array}$ & 0 \\
\hline
\end{tabular}




\begin{tabular}{c|l|c}
\hline 4. & $\begin{array}{l}\text { Explicitly associating the other with negative aspect } \\
- \text { personalizing, using the pronouns 'I' and 'you' } \\
\text { Ant. (...) Caesar, should I find them } \\
\text { So saucy with the hand of she here - what's her } \\
\text { name, } \\
\text { Since she was Cleopatra? (ANT 3.13.97-99) }\end{array}$ & 2 \\
\hline 5. & $\begin{array}{l}\text { Put the other's indebtedness on record } \\
\text { Caes. (...) but if you seek } \\
\text { To lay on me a cruelty, by taking } \\
\text { Antony's course, you shall bereave yourself } \\
\text { Of my good purposes, and put your children } \\
\text { To that destruction which I'll guard them from } \\
\text { If thereon you rely. (ANT 5.2.128-133) }\end{array}$ & 2 \\
\hline 6. & $\begin{array}{l}\text { Hindering/blocking - physically (block passage), } \\
\text { communicatively (deny turn, interrupt) (Bousfield) } \\
\text { Bru. Hear me, for I will speak. (JC 4.3.38) }\end{array}$ & 5 \\
\hline 7. & Enforcing role shift (Bousfield) & \multicolumn{1}{c}{ Total } \\
\hline
\end{tabular}

IN1 (Frightening - instilling a belief that action detrimental to the other will occur) is most frequently employed in my corpus of modals. Recall that in (2) the speaker Shylock employs the 'imperative (Repair thy wit) + or + the modal (WILL)' pattern:

$(13)(=(2))$ IN1 (Frighten - instill a belief that action detrimental to the other will occur)

Shy. Till thou canst rail the seal from off my bond,

Thou but offend'st thy lungs to speak so loud.

Repair thy wit, good youth, or it will fall

To cureless ruin. I stand here for law.

(MV 4.1.139-142)

This particular pattern, which typically co-occurs with proximal modals WILL, SHALL, and the contracted form 'LL, sounds threatening, since if the condition is not met, the speaker predicts that the future action will have a harmful effect (Nakayasu 2009: 90, 220-221). This can be very frightening to the hearer, and in this way the speaker attacks his negative face.

In fact, impoliteness strategies can be positively and negatively face damaging (Bousfield 2008: 132-133). Challenges, for example, can cause negative face damage as "they are equivalent to strong assertions that attempt to force the intended recipient to respond in a highly restricted and self-damaging way" 
(Bousfield 2008: 132); they can also cause positive face damage as "they all carry an underlying criticism of the intended recipient in some way" (Bousfield 2008: 133). Challenges, as a positive/negative impoliteness strategy (IP/N), attack the hearer's face, asking a challenging question typically with the modal used in an interrogative structure:

(14) IP/N: Challenges

Shy. (...)

What should I say to you? Should I not say, "Hath a dog money? Is it possible

A cur can lend three thousand ducats?" Or

Shall I bend low and in a bondman's key,

With bated breath and whisp'ring humbleness,

Say this:

"Fair sir, you spit on me on Wednesday last,

You spurn'd me such a day; another time

You call'd me dog; and for these courtesies

I'll lend you thus much moneys"?

(MV 1.3.120-129)

This strategy is recorded 40 times in the corpus. It is certainly not an insignificant number when considering the relationship between the modals and the strategies; this particular strategy alone accounts for $6.0 \%$ of all strategies. Since modals can be used to perform a rhetorical question, it is therefore challenging to the positive and negative sides of the face of the hearer.

\subsection{Modals and (im)politeness strategies}

Each (im)politeness strategy to save or attack face in relation to modals having been examined, this subsection will analyse each modal in more detail. Figure 1 illustrates the relationship between the strategies and the modals: 


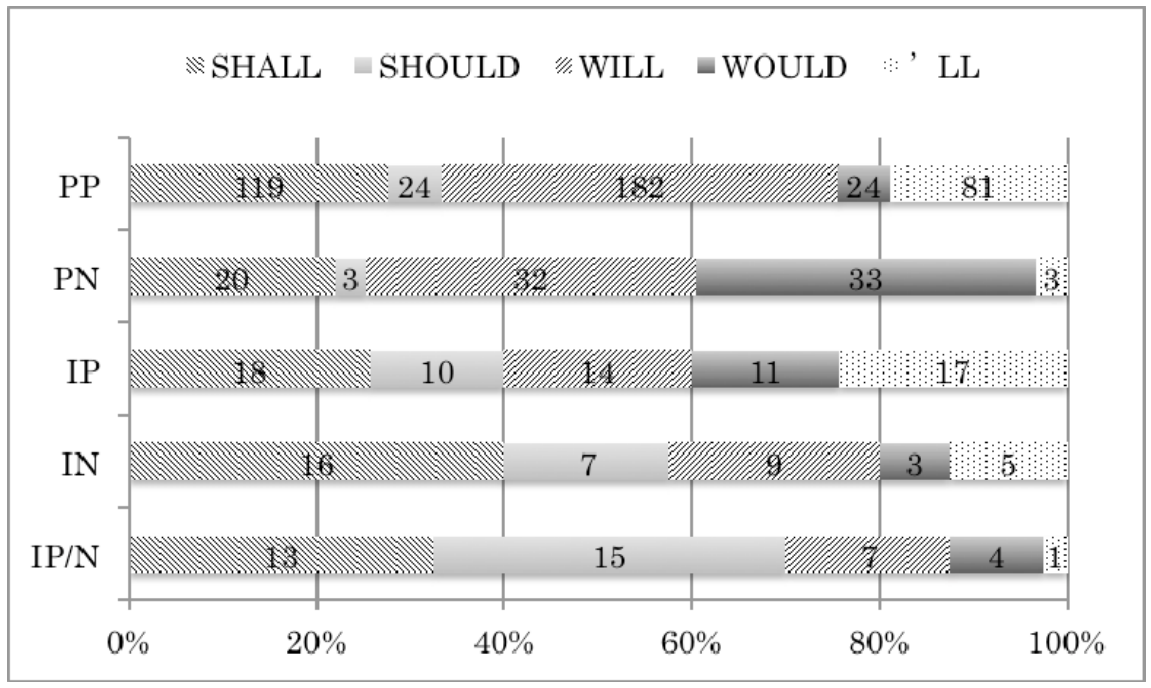

Figure 1. Modals used in (im)politeness strategies

Each bar shows the type of strategies and the breakdown for modals, SHALL, SHOULD, WILL, WOULD, and 'LL.

Proximal modals are more often used than distal modals in positive politeness strategies (PP). The instances and percentages of proximal modals are 382 instances (88.8\%), and those of distal modals are 48 instances (11.2\%). The reason for this is that these proximal modals are closely connected to the speech situation where the speaker and the hearer participate, which therefore enables the speaker to directly approach the positive face of the hearer (recall (1)).

Note, on the other hand, the high proportion of the distal modal WOULD (33 instances; 36.3\%) with negative politeness strategies (PN). The speaker pays attention to the hearer's wants not to be impeded by others. On the contrary, the proportion of SHOULD, which is also distal, is only 3.3\% (3 instances). In addition to these figures, what attracts our interest is that WILL enjoys almost the same high proportion (32 instances; $35.2 \%$ ) as WOULD. The modal WILL is oriented to dynamic modality, which is derived from its original lexical meaning 'volition' (Traugott (1972), Palmer (2001), Nakayasu (2009), etc.). In PN examples which accompany WILL, all but 2 are related to dynamic modality. Among them, PN1 is employed 17 times: the speaker pays attention to the hearer's intention (recall (10)).

Regarding positive impoliteness strategies (IP), the proportion of each modal is quite similar to each other, compared with other strategies. What seems to be working here is both proximal and distal senses of the modals. The proximal modals act directly to the hearer's positive face from the here and now of the 
speaker (recall (12)). The distal modals, on the other hand, attack the hearer's positive face by intentionally keeping away from his or her wants to approach the speaker:

(15) IP3 (Disassociate from the other - deny association or common ground with the other; avoid sitting together)

Ant. How now, lady?

Cleo. I would I had thy inches, thou shouldst know

There were a heart in Egypt.

Ant. Hear me, Queen:

(ANT 1.3.39-41)

Negative impoliteness strategies (IN), contrary to PN, are rather oriented towards deontic modality: SHALL (16 instances; 40.0\%) and SHOULD (7 instances; $17.5 \%$ ) enjoy a high frequency by comparison. Note that the original lexical meaning of these two modals is obligation, from which they developed deontic modality (Traugott (1972), Palmer (2001), Nakayasu (2009), etc.). With deontic modality, the conditioning factor is from outside sources such as the other speaker's intention. Although SHALL and SHOULD enjoy a high proportion of the cases of epistemic modality, their epistemic instances sometimes have a certain kind of obligation in their meaning. ${ }^{11}$ It seems that the speaker attacks the hearer's negative face by enforcing a kind of obligation on them (Recall (13)).

The bottom bar concerning positive/negative impoliteness strategies (IP/N) shows a more marked tendency towards deontic modality: SHALL (13 instances; 32.5\%) and SHOULD (15 instances; 37.5\%), the latter of which has the highest frequency rate in all types of the strategies. The speaker tends to ask a rhetorical question using these modals to attack both sides of the face as was already seen in (14).

11 In strong prediction or prophecy cases, the speaker judges that the future event is beyond human control (outside the will of the relevant individual) and destined to happen (Nakayasu 2009: 80). See also the breakdowns of modality in Nakayasu (2009: 78, 107), where epistemic modality shows a higher frequency compared with other types of modality: $45.5 \%$ for SHALL and $59.3 \%$ for SHOULD. This fact supports the high frequency of the prediction speech act for SHALL in Table 8. 


\subsection{Summary of (im)politeness strategies}

Figure 2 below is a summary of how often (im)politeness strategies are used in relation to modals: ${ }^{12}$

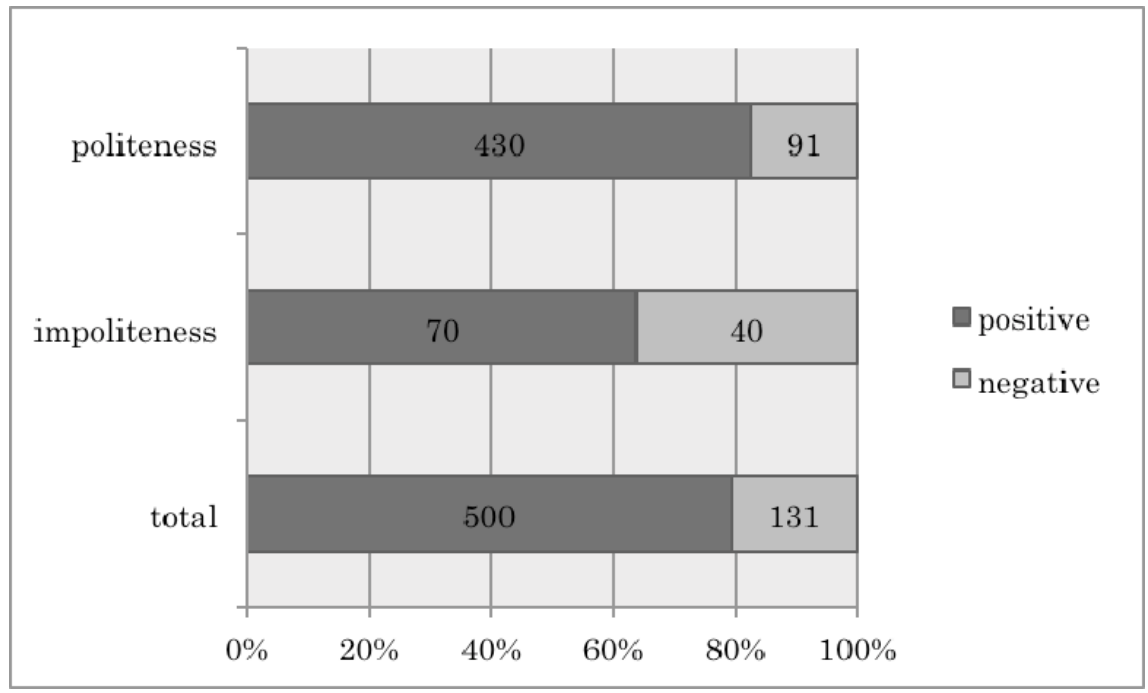

Figure 2. Summary of (im)politeness strategies in relation to modals

In both politeness and impoliteness, positive strategies are dominant. In total, 500 cases $(79.2 \%)$ are considered positive strategies, while 131 cases $(20.8 \%)$ are negative. It can be safely said from these figures that, at least where my corpus of modals is concerned, Shakespeare is positive (im)politeness-oriented. This is in line with the proposal by Kopytko $(1993,1995)$, although he analyses only politeness, not (im)politeness, without particular attention to modals.

\subsection{Interplay among strategies}

This subsection will observe the interplay among strategies, that is, positivepositive, negative-negative, and politeness-impoliteness strategies.

I will first look at the interplay among positive politeness strategies. In the previous context of (16), Antony was attacking Cleopatra's face, but in (16) he totally changes his mind to optimism, Cleopatra then following it. They employ proximal modals WILL and the contracted form successively as positive politeness strategies:

12 Note that strategies which can be considered to be both positive and negative are excluded from this figure. 
(16) Positive politeness strategies

Cleo. It is my birthday,

I had thought t' have held it poor; but since my lord

Is Antony again, I will be Cleopatra. [PP14]

Ant. We will yet do well. [PP11]

Cleo. Call all his noble captains to my lord.

Ant. Do so, we'll speak to them, and to-night I'll force

[PP11, PP11]

The wine peep through their scars. Come on, my queen,

There's sap in't yet. The next time I do fight,

$([\mathrm{PP} 12, \mathrm{PP} 4])^{13}$

I'll make death love me; for I will contend [PP11, PP11]

Even with his pestilent scythe.

(ANT 3.13.184-193)

The square brackets in the quotation indicate the type of strategy employed. For example, PP11 (Being optimistic that the hearer wants what the speaker wants, that the FTA is slight) and PP14 (Asserting reciprocal exchange or tit for tat) are exploited in the above.

In (17) below, Thidias is trying to persuade Cleopatra into following Caesar. He switches from positive politeness to negative politeness strategies (e.g. PN3 (Being pessimistic about ability or willingness to comply - using the subjunctive)), employing distal modals WOULD and SHOULD and paying full respect to her negative face:

(17) Negative politeness strategies

Thid. Shall I say to Caesar [PP10, PN1]

What you require of him? for he partly begs

To be desir'd to give. It much would please him, [PN7, PN3]

That of his fortunes you should make a staff [PN3]

To lean upon; but it would warm his spirits [PN3]

To hear from me you had left Antony,

And put yourself under his shroud,

The universal landlord.

(ANT 3.13.65-72)

The following context exemplifies the interplay between politeness and impoliteness strategies. The messenger reports to Cleopatra of what Antony has been doing recently, and upon hearing of his marriage, she becomes furious and

13 Here the strategies are not included in sentences with a modal. 
showers him with impoliteness strategies (e.g. IN1 (Frightening - instilling a belief that action detrimental to the other will occur)):

(18) Politeness vs. impoliteness strategies

Mess. Madam, he's married to Octavia.

Cleo. The most infectious pestilence upon thee!

Strikes him down.

Mess. Good madam, patience.

Cleo. What say you? Strikes him.

Hence,

Horrible villain, or I'll spurn thine eyes [IP11, IN1 $]^{14}$

Like balls before me; I' 11 unhair thy head, [IN1]

She hales him up and down.

Thou shalt be whipt with wire, and stew'd in brine, [IN1]

Smarting in ling'ring pickle.

(ANT 2.5.60-66)

Then the messenger begs her to listen to him, and she changes her attitude using positive politeness strategies (PP15 (Giving something desired: gifts, position, sympathy, understanding)); however, when he mentions Antony's marriage again, she suddenly switches back to impoliteness:

Mess. Gracious madam, [PN5]

I that do bring the news made not the match.

Cleo. Say 'tis not so, a province I will give thee, [PP15]

And make thy fortunes proud; the blow thou hadst

Shall make thy peace for moving me to rage, [PP15]

And I will boot thee with what gift beside [PP15]

Thy modesty can beg.

Mess. He's married, madam.

Cleo. Rogue, thou hast liv'd too long. Draws a knife.

[IP11, IN1]

Mess. Nay, then I'll run.

What mean you, madam? I have made no fault. Exit.

(ANT 2.5.66-74)

14 In this example, two impoliteness strategies are exploited in cooperation of one modal. For this reason they are counted as two separate strategies in Table 6 (IP) and Table 7 (IN). 
These sudden switches to and from politeness/impoliteness strategies skillfully depict Cleopatra's unstable mental state.

This section has observed how often and in what way modals are employed as (im)politeness strategies in interaction, both positive and negative. The next section will analyse the relationship between speech acts and (im)politeness.

\section{Speech acts and (im)politeness}

Speech acts are defined as actions performed via utterances (Austin 1962; Searle 1976, etc.). Speakers perform various kinds of speech acts in interaction. From the viewpoint of (im)politeness, Taavitsainen \& Jucker (2008: 7-9) point out that some speech acts can be face-threatening. It is therefore reasonable to say that the speaker performs a certain speech act to be polite or impolite to the hearer.

This section will examine how speech acts and (im)politeness strategies are interrelated with each other regarding the use of modals. As in the analysis of (im)politeness strategies, speech acts are analysed regarding the utterances including a modal and the context where they occur. Since there was not a clear distinction between main and subordinate clauses in Early Modern English, this research includes all the instances of the modals even though some of them do not seem to be related to any speech act. There are in fact a considerable number of instances to which not any speech act category is assigned in each modal. Such instances are categorised as 'no act' for each modal in Table 8 below. Expressions which reinforce a particular interpretation are also taken into consideration: for example, I will pronounce your sentence (LLL 1.1.300; declaration), then (JC 3.2.157; confirmation), what a wounding shame is this (ANT 5.2.159; expressive), Will you (JC 1.2.288; request), and I would say (ANT 1.1.28; IFID (illocutionary force indicating device)).

Table 8 shows the itemised list of speech acts which are performed with the modals and the number of instances of each modal in my corpus based on the inventory of speech acts proposed by Nakayasu (2009): ${ }^{15}$

15 The list in Table 8 is a revised version of the analysis of speech acts by Nakayasu (2009), whose corpus consists of three of Shakespeare's plays. For example, the act declaration guarantees that the propositional content corresponds to the world, while in the statement the speaker describes what he or she believes to be fact. I will not go deeply into the definition of other speech acts for lack of space. See Searle (1976) and Nakayasu (2009) for details. 
Table 8. Modals used in speech acts

\begin{tabular}{l|l|l|l|l|l|l}
\hline Speech act & SHALL & SHOULD & WILL & WOULD & 'LL & Total \\
\hline declaration & 7 & 0 & 0 & 0 & 0 & 7 \\
\hline statement & 21 & 42 & 40 & 37 & 4 & 144 \\
\hline prediction & 124 & 22 & 94 & 31 & 24 & 295 \\
\hline expressive & 1 & 13 & 5 & 32 & 0 & 51 \\
\hline insult & 2 & 2 & 0 & 0 & 1 & 5 \\
\hline intention & 33 & 0 & 63 & 34 & 29 & 159 \\
\hline decision & 29 & 0 & 116 & 0 & 71 & 216 \\
\hline promise & 27 & 1 & 52 & 1 & 38 & 119 \\
\hline threat & 15 & 1 & 6 & 1 & 10 & 33 \\
\hline assurance & 16 & 1 & 5 & 0 & 0 & 22 \\
\hline order & 10 & 1 & 1 & 0 & 0 & 12 \\
\hline prohibition & 7 & 0 & 1 & 0 & 0 & 8 \\
\hline advice & 0 & 1 & 1 & 0 & 0 & 2 \\
\hline request & 12 & 1 & 21 & 2 & 4 & 40 \\
\hline permission & 10 & 0 & 0 & 0 & 0 & 10 \\
\hline proposal & 16 & 0 & 24 & 0 & 15 & 55 \\
\hline offer & 3 & 0 & 2 & 0 & 1 & 6 \\
\hline question & 48 & 30 & 23 & 24 & 0 & 125 \\
\hline confirmation & 5 & 2 & 7 & 4 & 3 & 21 \\
\hline IFID & 0 & 0 & 0 & 2 & 0 & 2 \\
\hline no act & 89 & 75 & 113 & 80 & 12 & 369 \\
\hline Total & 475 & 192 & 574 & 248 & 212 & 1,701 \\
\hline & & & & & &
\end{tabular}

The modal SHALL performs a wide variety of speech acts, with prediction (124 instances) the most common one. Regarding WILL, instant decision making (116 instances) is the most frequently performed, though prediction (94 instances) comes second. Their distal forms, SHOULD and WOULD, on the other hand, have a limited repertoire, and statement, where the speaker states what he/she believes to be true (42 and 37 instances, respectively), is the most frequently performed among those speech acts. The contracted form 'LL has the most limited repertoire, with decision (71 instances) most frequently performed.

The following data in Table 9 was obtained by conducting a statistical analysis of the relationship between speech acts and (im)politeness strategies. It represents the intersection of the 641 modals used in (im)politeness strategies and the 1,332 modals employed in speech acts. ${ }^{16}$ Each number shows that the

1631 modal instances are assigned more than one strategy category. 
same utterance is exploited to perform a certain kind of speech act as well as to be used as a certain kind of (im)politeness strategy, either positive or negative:

Table 9. Relations between speech acts and (im)politeness strategies

\begin{tabular}{l|l|l|l|l|l|l}
\hline Speech act & PP & PN & IP & IN & IP/N & Total \\
\hline declaration & 0 & 0 & 0 & 0 & 0 & 0 \\
\hline statement & 27 & 1 & 8 & 1 & 0 & 37 \\
\hline prediction & 55 & 10 & 9 & 4 & 0 & 78 \\
\hline expressive & 5 & 1 & 3 & 0 & 3 & 12 \\
\hline insult & 0 & 0 & 3 & 1 & 0 & 4 \\
\hline intention & 34 & 5 & 14 & 3 & 1 & 57 \\
\hline decision & 74 & 1 & 9 & 2 & 0 & 86 \\
\hline promise & 102 & 1 & 0 & 0 & 0 & 103 \\
\hline threat & 0 & 0 & 5 & 19 & 0 & 24 \\
\hline assurance & 7 & 1 & 0 & 0 & 0 & 8 \\
\hline order & 1 & 0 & 0 & 0 & 0 & 1 \\
\hline prohibition & 3 & 0 & 0 & 1 & 0 & 4 \\
\hline advice & 0 & 0 & 0 & 0 & 0 & 0 \\
\hline request & 6 & 18 & 1 & 1 & 0 & 26 \\
\hline permission & 3 & 5 & 0 & 0 & 0 & 8 \\
\hline proposal & 33 & 2 & 0 & 0 & 0 & 35 \\
\hline offer & 5 & 0 & 0 & 0 & 0 & 5 \\
\hline question & 4 & 7 & 0 & 2 & 29 & 42 \\
\hline confirmation & 7 & 1 & 2 & 0 & 1 & 11 \\
\hline IFID & 0 & 2 & 0 & 0 & 0 & 2 \\
\hline Total & 366 & 55 & 54 & 34 & 34 & 543 \\
\hline Percentage & 67.4 & 10.1 & 9.9 & 6.3 & 6.3 & 100.0 \\
\hline & & & & & &
\end{tabular}

Note that there are 1,060 utterances not related to any (im)politeness strategies, which have been naturally excluded from the list. It is also helpful to note, in passing, that $31.3 \%$ (532 instances) of the total of 1,701 modal instances are categorised as occurring in both speech acts and (im)politeness strategies. Of the 1,332 instances assigned to speech act categories, 39.9\% (532 instances) are also assigned to (im)politeness strategy categories.

Let us now examine several cases where a particular speech act has a strong connection to a particular (im)politeness strategy. Recall the first example, where the speaker makes a promise: 
(20) (=(1)) Promise, PP10 (Offer, promise)

Ar. (...)

Sweet, adieu. I'll keep my oath,

Patiently to bear my wroth.

(MV 2.9.77-78)

This is exactly where speech act and (im)politeness meet: making a promise is also a positive politeness strategy, as already seen in the introduction. Moreover, among all the cases where the same utterance is exploited as a speech act and an (im)politeness strategy, this type is the most frequent in my corpus (102 instances). It should also be noted that all instances of the offers (5 instances) and many of the proposals (33 out of 35; 94.3\%) and the decisions (74 out of $86 ; 86.0 \%$ ) are used as positive politeness strategies.

Whereas promise guarantees that something beneficial to the hearer will happen, the speaker threatens the hearer by assuring that something evil will occur to the hearer. Threats and insults are by their nature all impolite to the hearer, and one of the typical examples is the threat used as IN1 (Frightening instilling a belief that action detrimental to the other will occur), as seen in (2):

(21) (=(2)) Threat, IN1 (Frightening - instilling a belief that action detrimental to the other will occur)

Shy. Till thou canst rail the seal from off my bond,

Thou but offend'st thy lungs to speak so loud.

Repair thy wit, good youth, or it will fall

To cureless ruin. I stand here for law.

(MV 4.1.139-142)

The request is the speech act to ask the hearer to do something. This speech act is often performed in an indirect way such as an interrogative sentence with a modal as in (10) (15 instances in my corpus):

(22) (=(10)) Request, PN1 (Be conventionally indirect)

Bass. May you stead me? Will you pleasure me?

Shall I know your answer?

Shy. Three thousand ducats for three months, and Antonio bound.

(MV 1.3.7-10)

The speaker successively employs the modals MAY, WILL, and SHALL in interrogatives paying high respect to the negative face of the hearer Shylock, because he knows that otherwise he would not lend money to his friend Antonio. 
Predictions are very frequently performed with the aid of modals, and what directs our special attention to this speech act is that it can be anything (im)polite, namely, polite or impolite, and positive or negative, although PP is the most frequent strategy adopted in my corpus (55 out of 78 instances; $70.5 \%$ ). Shown below is an example of positive impoliteness strategy, where the princess disagrees with the king:

(23) Prediction, IP7 (Seek disagreement - select a sensitive topic) Prin. When you then were here,

What did you whisper in your lady's ear?

King. That more than all the world I did respect her.

Prin. When she shall challenge this, you will reject her.

King. Upon mine honor, no.

(LLL 5.2.435-439)

The intention, which is related to dynamic modality, can also be related to these strategies, i.e. PP, PN, IP, and IN. In the example below, the speaker Shylock expresses his strong intention by the positive and negative forms of WILL and 'LL and employs IP1 to ignore the hearer Antonio's request I pray thee hear me speak:

(24) (=(12)) Intention, IP1 (Ignoring, snubbing the other - failing to acknowledge the other's presence)

Ant. I pray thee hear me speak.

Shy. I'll have my bond; I will not hear thee speak.

I'll have my bond, and therefore speak no more.

I'll not be made a soft and dull-ey'd fool

To shake the head, relent, and sigh, and yield

To Christian intercessors. Follow not,

I'll have no speaking, I will have my bond. Exit Jew.

(MV 3.3.11-17)

There are two kinds of questions, namely, information-seeking questions and rhetorical questions (Arnovick 1990). While information-seeking questions sound polite to the hearer by showing interest in his/her face, rhetorical questions can be impolite. Recall the discussion in 2.2, where impoliteness strategies were found to be threatening to both positive and negative sides. In (25) below Shylock employs rhetorical questions successively using modals SHOULD and SHALL and an epistemic adjective possible: 
(25) (=(14)) Question, IP/N (Challenge))

Shy. (...)

What should I say to you? Should I not say,

"Hath a dog money? Is it possible

A cur can lend three thousand ducats?" Or

Shall I bend low and in a bondman's key,

With bated breath and whisp'ring humbleness,

Say this:

"Fair sir, you spit on me on Wednesday last,

You spurn'd me such a day; another time

You call'd me dog; and for these courtesies

I'll lend you thus much moneys"?

(MV 1.3.120-129)

By doing so he is challenging both sides of the hearer's face. This pattern is quite frequently found in my corpus (26 out of $42 ; 61.9 \%$ ).

Table 9 and the quotations from Shakespeare's plays show that modality, speech acts and (im)politeness strategies are interrelated to each other, and that the percentage of speech acts performed also as positive politeness strategies is by far the highest out of the speech acts which are also used as some kind of (im)politeness strategy (366 out of 543 instances; 67.4\%). Recall the results of statistical analysis of (im)politeness strategies used in relation to modals in Figure 2, which also demonstrates that a considerable number of positive politeness strategies are employed. Here again, it is shown that positive politeness strategies have a stronger connection than other strategies to the speech acts performed using modals.

\section{Conclusion}

This paper has sought to explain how modals are interrelated with speech acts and (im)politeness in line with historical pragmatics and historical (im)politeness to offer a new perspective to the interactions in Shakespeare's plays. Within the frameworks of Brown \& Levinson (1987); Culpeper (1996); Culpepr \& Kádár (2010) and Nakayasu (2009), statistic and contextual analyses have been conducted of the utterances which include proximal modals SHALL and WILL, distal modals SHOULD and WOULD, and the contracted form 'LL.

Embarking on a brief definition of politeness and its negative counterpart impoliteness, this study revealed that a variety of strategies are employed with modals to save or attack the hearer's positive or negative face. The examination of the relationship between each modal and these strategies showed a strong connection of the proximal modals to positive politeness strategies (PP). It was 
also pointed out that some strategies indicate a stronger tendency towards particular modality, for example, IN and I/PN to deontic modality. It was observed in the interplay among strategies that modals play an active role in saving and attacking face. The statistical analysis of these strategies confirmed that the interactions in Shakespeare are positive (im)politeness-oriented. Furthermore, the present study analysed how speech acts performed with the aid of modals are associated with (im)politeness strategies. A stronger connection again was found between speech acts and positive politeness strategies.

To summarise, there are more strategies to save or attack the hearer's positive face employed with modals in Shakespeare than there are strategies to save or attack the hearer's negative face. The analysis reinforced the proposal by Kopytko $(1993,1995)$ that social interactions in Shakespeare's time were positive politeness-oriented. The present study went further to extend the analysis to impoliteness, incorporating the meaning and function of modals, and also suggested the interrelated nature of modality, speech acts and (im)politeness.

This research aimed to offer a new perspective on interactions in Shakespeare's plays. Much still remains to be done, however. To begin with, it is worthwhile examining whether the same observations are applicable to other modals, such as CAN and MAY. Next, enlarging the scope of the corpus may provide a clearer and more detailed picture of sociopragmatic aspects in Shakespeare and Early Modern English. Finally, it is necessary to capture this phenomenon in a diachronic perspective, since the quality of (im)politeness has changed over time, as rightly pointed out by Jucker $(2011,2012)$. If the framework by Brown \& Levinson (1987) applies exclusively to certain periods such as Modern English, it will certainly call for a possible new framework to map the whole history of human interactions in a comprehensive way.

\section{REFERENCES}

Arnovick, Leslie Katharine. 1990. The development of future constructions in English: The pragmatics of modal and temporal will and shall in Middle English (Berkeley Insights in Linguistics and Semiotics 2). New York, etc.: Peter Lang.

Arnovick, Leslie Katharine. 1999. Diachronic pragmatics: Seven case studies in English illocutionary development (Pragmatics \& Beyond New Series 68). Amsterdam \& Philadelphia: John Benjamins Publishing Company.

Austin, John Langshow. 1962. How to do things with words: The William James Lectures delivered at Harvard University in 1955. Oxford, etc.: Oxford University Press.

Bax, Marcel \& Dániel Z. Kádár. 2011. The historical understanding of historical (im)politeness. Journal of Historical Pragmatics 12. 1-24. 
Bousfield, Derek. 2008. Impoliteness in interaction (Pragmatics \& Beyond New Series 167). Amsterdam \& Philadelphia: John Benjamins Publishing Company.

Boyd, Julian \& James Peter Thorne. 1969. The semantics of modal verbs. Journal of Linguistics 5. 57-74.

Brown, Penelope \& Steven Curtis Levinson. 1987. Politeness: Some universals in language usage. Cambridge, etc.: Cambridge University Press.

Brown, Roger \& Albert Gilman. 1989. Politeness theory and Shakespeare's four major tragedies. Language in Society 18. 159-212.

Culpeper, Jonathan. 1996. Towards an anatomy of impoliteness. Journal of Pragmatics 25. 349367.

Culpeper, Jonathan \& Dániel Z. Kádár (eds.). 2010. Historical (im)politeness (Linguistic Insights: Studies in Language and Communication 65). Bern, etc.: Peter Lang.

Diessel, Holger. 1999. Demonstratives: Form, function, and grammaticalization (Typological Studies in Language 42). Amsterdam \& Philadelphia: John Benjamins Publishing Company.

Evans, Gwyne Blakemore (ed.). 1997. The Riverside Shakespeare. Boston \& New York: Houghton Mifflin Company.

Fillmore, Charles John. 1975 [1997]. Sant Cruz Lectures on Deixis, 1971. Indiana: Indiana Linguistics Club. [Reprinted in: Charles John Fillmore. 1997. Lectures on deixis. Stanford: CSLI Publications.]

Gotti, Maurizio, Marina Dossena, Richard Dury, Roberta Facchinetti \& Maria Lima. 2002. Variation in central modals: A repertoire of forms and types of usage in Middle English and Early Modern English (Linguistic Insights: Studies in Language and Communication 4). Bern, etc.: Peter Lang.

Jacobs, Andreas \& Andreas H. Jucker. 1995. The historical perspective in pragmatics. In Andreas H. Jucker (ed.), Historical pragmatics: Pragmatic developments in the history of English (Pragmatics \& Beyond New Series 35), 3-33. Amsterdam \& Philadelphia: John Benjamins Publishing Company.

Jucker, Andreas H. 2008. Politeness in the history of English. In Richard Dury, Maurizio Gotti \& Marina Dossena (eds.), English historical linguistics 2006: Selected papers from the Fourteenth International Conference on English Historical Linguistics (ICEHL 14), Bergamo, 21-25 August 2006, 3-29. Amsterdam \& Philadelphia: John Benjamins Publishing Company.

Jucker, Andreas H. 2011. Positive and negative face as descriptive categories in the history of English. Journal of Historical Pragmatics 12. 178-197.

Jucker, Andreas H. 2012. Changes in politeness cultures. In Terttu Nevalainen \& Elizabeth Closs Traugott (eds.), The Oxford handbook of the history of English, 422-433. New York: Oxford University Press.

Jucker, Andreas H. \& Irma Taavitsainen. 2008. Apologies in the history of English: Routinized and lexicalized expressions of responsibility and regret. In Andreas H. Jucker \& Irma Taavitsainen (eds.), Speech acts in the history of English (Pragmatics \& Beyond New Series 176), 229-244. Amsterdam \& Philadelphia: John Benjamins Publishing Company.

Kohnen, Thomas. 2008. Directives in Old English. In Andreas H. Jucker \& Irma Taavitsainen (eds.), Speech acts in the history of English (Pragmatics \& Beyond New Series 176), 27-44. Amsterdam \& Philadelphia: John Benjamins Publishing Company.

Kopytko, Roman. 1993. Polite discourse in Shakespeare's English. Poznań: Wydawnictwo Naukowe Uniwersytetu im. Adama Mickiewicza w Poznaniu. 
Kopytko, Roman. 1995. Linguistic politeness strategies in Shakespeare's plays. In Andreas H. Jucker (ed.), Historical pragmatics: Pragmatic developments in the history of English (Pragmatics \& Beyond New Series 35), 515-540. Amsterdam \& Philadelphia: John Benjamins Publishing Company.

Nakayasu, Minako. 2009. The pragmatics of modals in Shakespeare (Polish Studies in English Language and Literature 30). Frankfurt am Main, etc.: Peter Lang.

Nevala, Minna. 2010. Politeness. In Andreas H. Jucker \& Irma Taavitsainen (eds.), Historical pragmatics (Handbook of Pragmatics 8), 419-450. Amsterdam \& Philadelphia: John Benjamins Publishing Company.

Nevalainen, Terttu \& Helena Raumolin-Brunberg (eds.). 1996. Sociolinguistics and language history: Studies based on the Corpus of Early English Correspondence (Language and Computers: Studies in Practical Linguistics 15). Amsterdam \& Atlanta: Editions Rodopi B. V.

Oakeshott-Taylor, John. 1984. Factuality, tense, intonation and perspective: Some thoughts on the semantics of 'think'. Lingua 62. 289-317.

Palmer, Frank Robert. 2001. Mood and modality, 2nd edn. (Cambridge Textbooks in Linguistics). Cambridge, etc.: Cambridge University Press.

Rudanko, Juhani. 2006. Aggravated impoliteness and two types of speaker intention in an episode in Shakespeare's Timon of Athens. Journal of Pragmatics 38. 829-841.

Searle, John Rogers. 1976. A classification of illocutionary acts. Language in Society 5. 1-23.

Spevack, Marvin (ed.). 1968-1980. A complete and systematic concordance to the works of Shakespeare. 9 vols. Hildesheim: Georg Olms Verlag.

Taavitsainen, Irma \& Andreas H. Jucker. 2008. Speech acts now and then. In Andreas H. Jucker \& Irma Taavitsainen (eds.), Speech acts in the history of English (Pragmatics \& Beyond New Series 176), 1-23. Amsterdam \& Philadelphia: John Benjamins Publishing Company.

Traugott, Elizabeth Closs. 1972. A history of English syntax: A transformational approach to the history of English sentence structure (The Transatlantic Series in Linguistics). New York, etc.: Holt, Rinehart and Winston. 